\title{
Kodeksy dobrych praktyk jako wyraz społecznej odpowiedzialności korporacji
}

Przypatrując się z „lotu ptaka” przeobrażeniom ustawodawstwa pracy w naszym kraju można zauważyć, że wśród niezliczonych meandrów spowodowanych okolicznościami polityki wewnętrznej są one w rosnącym stopniu wyrazem umiędzynarodowienia krajowego porządku prawnego. Wynika to z międzynarodowych zobowiązań Polski oraz ciśnienia współczesnych wzorców cywilizacyjnych.

Za najwcześniejszy przejaw tej internacjonalizacji można uznać proces dostosowywania prawa polskiego do konwencji i zaleceń Międzynarodowej Organizacji Pracy, której Polska była państwem współzałożycielskim. Stopień przyswojenia dorobku MOP stawia Polskę w czołówce państw należących do tej organizacji ${ }^{1}$.

W III Rzeczpospolitej można mówić o europeizacji prawa pracy, której pierwszym etapem było uwzględnienie postanowień Europejskiej Karty Społecznej Rady Europy, zwłaszcza w sformułowaniach podstawowych zasad prawa pracy dotyczących m.in. prawa do pracy czy prawa do godziwego wynagrodzenia za pracę. Największe znaczenie miało oczywiście przyswojenie dorobku prawnego Unii Europejskiej na poziome prawa traktatowego i prawa wtórnego, co pod wieloma względami przeobraziło kształt prawa pracy w naszym kraju. Nawiasem mówiąc, odbywało się to nie zawsze racjonalnie i nie zawsze w sposób wymuszający dostosowanie praktyki do europejskich standardów.

* Prof. zw. dr. hab., kierownik Zakładu Prawa Pracy Instytutu Nauk Prawnych PAN, kierownik Zakładu Prawa Pracy i Zabezpieczenia Społecznego w Instytucie Pracy i Spraw Socjalnych, były kierownik Katedry Prawa Cywilnego i Prawa Pracy na Wydziale Prawa i Administracji Uniwersytetu Rzeszowskiego. Członek Komitetu Nauk o Pracy i Polityce Społecznej PAN.

${ }^{1}$ Nie zmienia tej oceny fakt, że w okresie PRL niektóre prawa podstawowe proklamowane przez MOP stosowane były opacznie (w szczególności prawa związkowe w ustroju totalitarnym). 
Wiele wskazuje na to, że stosunki pracy czy szerzej stosunki gospodarcze, $\mathrm{w}$ tym stosunki pracy, zostaną w niedalekiej przyszłości na większą skalę skonfrontowane z kolejnym naporem internacjonalizacji, jakim jest prawo korporacyjne, czyli prawo tworzone $\mathrm{w}$ ramach dużych, złożonych organizmów gospodarczych, częstokroć rozgałęzionych na wiele krajów, nierzadko opasających cały glob ziemski. Noszą one wówczas nazwę przedsiębiorstw wielonarodowych lub transnarodowych (ang. Multinational Enterprises).

$\mathrm{O}$ ile dotychczasowe trendy związane $\mathrm{z}$ implementacją dorobku Międzynarodowej Organizacji Pracy, obu organizacji paneuropejskich (RE i UE) oraz innych organizacji międzynarodowych (zwłaszcza ONZ i jej agend), uznamy zbiorczo za przejaw internacjonalizacji pierwszego stopnia, to wpływ wywierany przez normy ustanawiane w korporacjach należałoby uznać za przejaw internacjonalizacji prawa drugiego stopnia. Różnica jest bowiem jakościowa. W pierwszym przypadku czynnikiem sprawczym umiędzynarodowienia prawa (stosunków) pracy są organizacje międzynarodowe skupiające państwa. Natomiast w drugim źródłem norm są same organizacje gospodarcze (spółki kapitałowe) działające samodzielnie lub w porozumieniu z czynnikiem pracowniczym.

Znaczenie norm ustalanych w korporacjach dla krajowych stosunków pracy wynika z procesu globalizacji, przez który rozumie się nieodwracalny i nieodwołalny proces intensyfikacji międzynarodowej integracji gospodarczej². Globalizacja stosunków pracy dokonuje się w drodze stworzenia systemu zależności wnoszonego do firm przez międzynarodowe korporacje opanowujące rynek kapitału i pracy wskutek prywatyzacji i inwestycji zagranicznych ${ }^{3}$.

W ostatnim czasie obserwuje się gwałtowny wzrost liczby korporacji. Według danych Konferencji Narodów Zjednoczonych do spraw Handlu i Rozwoju (UNCTAD) liczba działających na poziomie ponadnarodowym korporacji wzrosła z siedmiu tysięcy w 1970 r. do 82 tysięcy w 2008 r. ${ }^{4}$ Poszczególne korporacje dysponują budżetami dalece przekraczającymi budżety wielu państw. Stale też wzrasta ich rola w zakresie udziału w światowych inwestycjach ${ }^{5}$.

${ }^{2}$ Por. J. Boruta, W sprawie przyszłości prawa pracy, "Praca i Zabezpieczenie Społeczne” 2005, nr 4, s. 4, cytująca poglądy uczonych zachodnioeuropejskich, wśród których niektórzy wieszczą wynikające z globalizacji i innych przesłanek obumieranie prawa pracy.

${ }^{3}$ Por. J. Craig, M. Lynk, Labour Law and Globalization, [w:] Globalization and the Future of Labour Law, J.D.R. Craig, S.M. Lunk, Cambridge University Press, Cambridge 2006, s. 12.

${ }^{4}$ Dane te przytaczam za S. Adamczykiem i B. Surdykowska, Międzynarodowe układy ramowe jako przykład dobrowolnie podejmowanych negocjacji między praca a kapitałem, [w:] Układy zbiorowe pracy. W stulecie urodzin Profesora Wactawa Szuberta, red. Z. Góral, Lex Wolters Kluwer business, Warszawa 2013, s. 131.

${ }^{5}$ Por. przygotowane na zlecenie Międzynarodowego Biura Pracy opracowanie I. Mamica, Business and Code of Conduct Implementation, Geneve 2006, s. 9. 
Jednocześnie z procesem koncentracji kapitału w skali światowej obserwuje się proces rozdrabniania struktur pracodawczych ${ }^{6}$. Rozdrobnienie to oznacza tworzenie się układów złożonych, których typowym przejawem jest holding składający się ze spółki dominującej (matki) oraz spółek zależnych (córek). W takiej strukturze mamy do czynienia z ośrodkiem decyzyjnym usytuowanym w spółce dominującej i z zachowującymi podmiotowość prawną spółkami filialnymi powiązanymi kapitałowo $\mathrm{z}$ ogniwem centralnym. W orbicie takich układów złożonych znajdują się dalsze podmioty: kontrahenci i podwykonawcy, a więc kształtują się sieci powiązań biznesowych.

Skomplikowane, wielopodmiotowe, struktury gospodarcze w warunkach wolnego handlu przekraczają granice państw. W wielu miejscach globu, jak mówiliśmy, powstają filie spółek dominujących, co stanowi najbardziej charakterystyczny przejaw globalizacji ${ }^{7}$.

Jak wyżej wspomniano, w korporacjach, zwłaszcza tych rozgałęzionych na wiele krajów, ustanawiane są normy dotyczące ich roli i działalności, mające także aspekty prawnopracownicze.

Prawo korporacyjne rozwija się dwutorowo - na drodze negocjacyjnej oraz poprzez autoregulację. Pierwszą ścieżką rozwoju, bardziej ukierunkowaną na ochronę praw i interesów pracowniczych, jest praktyka zawierania tzw. porozumień ramowych z centralami korporacji (zarządami spółek dominujących) przez europejskie lub globalne federacje związków zawodowych bądź przez pozazwiązkowe reprezentacje pracowników, wśród których należy w szczególności wskazać europejskie rady zakładowe. Porozumienia te noszą nazwę ponadnarodowych porozumień korporacyjnych (ang. Transnational Company Agreements, w skrócie: TCA). Dzielą się one na Europejskie Porozumienia Ramowe (ang. European Framework Agreements, w skrócie: EFA) oraz Międzynarodowe Porozumienia Ramowe (ang. International Framework Agreements, w skrócie: IFA). Nacisk na zawieranie porozumień ramowych stanowi odpowiedź związków zawodowych na procesy globalizacji. W porozumieniach określa się m.in. minimalne standardy pracy, w tym dotyczące spraw z zakresu stosunków pracy (promowanie umów na czas nieokreślony, tzw. płacy życiowej,

${ }^{6}$ Jak pisze P. Czarnecki, obserwowane zjawisko koncentracji (integracji) gospodarczej charakteryzuje „schyłek wielkich przedsiębiorców o jednolitej podmiotowości prawnej oraz rozwój sieci i ugrupowań integracyjnych przedsiębiorców, którzy mimo iż posiadają odrębna, niezależną osobowość prawną, pozostają w ścisłym związku", P. Czarnecki, Odpowiedzialność pracodawcy a rozwój struktur holdingowych, Warszawa 2014, s. 35.

7 Oczywiście podobnego rodzaju organizmy gospodarcze mogą mieć zasięg regionalny, jak np. spółka europejska bądź też zasięg ograniczony do danego państwa. W tym ostatnim przypadku prawo korporacyjne pozbawiane jest aspektu międzynarodowego, co wpływa także na charakter kodeksów etycznych przyjmowanych w takich organizacjach. W niniejszym artykule skupiam się przede wszystkim na praktykach stosowanych w przedsiębiorstwach transnarodowych. 
urlopy, praca w godzinach nadliczbowych itp.). Pod pewnymi względami upodobniają się do układów zbiorowych, chociaż ich mankamentem jest to, że stanowią wytwór praktyki pozbawiony niekwestionowanych podstaw prawnych $\mathrm{w}$ prawie międzynarodowym (europejskim), co stawia pod znakiem zapytania ich skuteczność. W związku z powyższym zgłaszane są postulaty ustanowienia takich podstaw ${ }^{8}$.

Niewątpliwym atutem porozumień, o których mowa, jest ich powstawanie na drodze negocjacyjnej. Są więc owocem dialogu społecznego prowadzonego na szczeblu korporacji. Cechy tej pozbawione są kodeksy dobrych praktyk (Codes of Conduct) będące przejawem autoregulacji podmiotów gospodarczych. Ponadto, co należy zaznaczyć na wstępie, problematyka związana z prawem pracy w sposób bezpośredni lub pośredni nie stanowi, w odróżnieniu od wzmiankowanych porozumień, centrum zainteresowania kodeksów dobrych praktyk (chociaż w istotnym stopniu w sposób bezpośredni i, bardziej, pośredni odnoszą się one do stosunków pracy). Kodeksy etyczne oparte są bowiem na innym paradygmacie. Również one, podobnie jak porozumienia ramowe, stanowią wytwór praktyki rozwijającej się żywiołowo szczególnie od połowy lat osiemdziesiątych wieku XX. W związku z nieugruntowanym prawnie charakterem nie ma też - poza definicjami znajdującymi zastosowanie na użytek wąskiej dziedziny stosunków gospodarczych ${ }^{9}$ - oficjalnej definicji tego rodzaju dokumentów. Według propozycji Międzynarodowego Biura Pracy, kodeks dobrych praktyk powinien być rozumiany jako ustanowienie zasad biznesowych określających całokształt stosunków w zakresie problemów występujących miedzy daną organizacją a jej interesariuszami ${ }^{10}$.

${ }^{8}$ Problematykę porozumień ramowych w naszej literaturze omawiali ostatnio S. Adamczyk i B. Surdykowska. Por. tych autorów Ponadnarodowe układy ramowe jako próba odpowiedzi związków zawodowych na wyzwania globalizacji, „Praca i Zabezpieczenie Społeczne" 2012, nr 1 oraz tychże autorów pozycja cytowana w przypisie 4. Por. również M. Gładoch, Dialog społeczny w zbiorowym prawie pracy, Toruń 2014 - rozdział VII zatytułowany Dialog $i$ wspótpraca partnerów społecznych w epoce globalizacji, s. 237 i nast.

9 Zgodnie z dyrektywą 2005/29 WE z dnia 11 maja 2005 r. o nieuczciwych praktykach handlowych (DzU UE L z dnia 11 czerwca 2005 r.), „Kodeks postępowania oznacza umowę lub zbiór zasad, które nie są wymagane na mocy przepisów ustawowych, wykonawczych lub administracyjnych Państwa Członkowskiego i które definiują postępowanie przedsiębiorców, którzy zobowiązali się do przestrzegania Kodeksu w odniesieniu do jednej lub większej liczby określonych praktyk handlowych lub sektorów działalności gospodarczej". To postanowienie dyrektywy implementuje polska ustawa z dnia 23 sierpnia $2007 \mathrm{r}$. o przeciwdziałaniu nieuczciwym praktykom rynkowym (DzU, 2007, nr 171, poz. 1206), por. definicję kodeksu dobrych praktyk z art. 2 ust. 5 tej ustawy.

10 "In the most general sense, a Code of Conduct may be understood as a statement of business principles defining a set of relationships on a range of topics between an entity and its stakeholders", International Labour Office, Codes of Conduct for Multinational Enterprises, ILO, Geneva 2002, Chapter 1. 
W definicji tej uwypukla się kompleksowość treści dokumentów, o których mowa, dzięki czemu zasługują one na miano kodeksów.

Należy podkreślić, że jednostronne zobowiązania korporacji względem grup interesariuszy są w zasadzie natury etycznej. Mieszczą się one w kategoriach tzw. społecznej odpowiedzialności korporacji (ang. Corporate Social Responsibility, w skrócie: CSR), toteż w zasadzie nie stanowią podstaw do egzekwowania roszczeń. Nie oznacza to, że postanowienia kodeksów pozbawione są znaczenia prawnego, o czym będzie mowa w dalszej części artykułu. Przyjęcie kodeksu dobrych praktyk jest dla organizacji dobrowolne, jednakże bywa niekiedy warunkiem członkostwa w zrzeszeniach przedsiębiorców. Można więc mówić o pewnych standardach obowiązujących w świecie biznesu. Głównym jednak powodem ustanawiania kodeksów jest potrzeba autoprezentacji - przedstawienia korzystnego wizerunku firmy jako stawiającej przed sobą wysokie wymagania etyczne w stosunkach z grupami interesariuszy, co służy zarazem podniesieniu efektywności ekonomicznej korporacji. Za nadrzędną ideę, stanowiącą niejako wartość scalającą kodeksów etycznych, uznaje się pojęcie ładu korporacyjnego (ang. corporate governance), czyli struktury decyzyjnej ukierunkowanej na osiągnięcie celu społecznej odpowiedzialności organizacji gospodarczej. Warunkiem stworzenia takiego ładu jest zapewnienie efektywnego nadzoru właścicielskiego nad spółką i ochrona praw akcjonariuszy.

Kompletnie ukształtowany kodeks dobrych praktyk składa się z kilku typowych zakresów tematycznych. Na czoło wysuwa się warstwa aksjologiczna kodeksów. Stanowią one zbiory wartości, jakimi organizacja jako całość wraz z jej bliższymi i dalszymi ogniwami oraz osoby zarządzające i pracownicy powinni się kierować w swoim postępowaniu względem poszczególnych grup interesariuszy. Są to wartości uniwersalne tj. niesporne i powszechnie uznawane (na drodze intuicji etycznej bądź przez odwołanie się do fundamentalnych aktów międzynarodowych), które zarazem eksponuje się w kodeksach jako wartości korporacyjne cechujące obywatela korporacji (ang. corporate citizen). Są to także podstawowe zasady, jakimi korporacja kieruje się $\mathrm{w}$ chęci realizacji polityki $C S R^{11}$.

${ }^{11}$ I tak przykładowo, według Kodeksu Etyki Toyota Motor Corporation, w korporacji obowiązuje siedem „Fundamentalnych Zasad Toyoty”, którymi są:

1. Honorowanie języka i ducha prawa każdego kraju oraz podejmowanie otwartych i godziwych działań korporacyjnych tak, by firma stała się dobrym obywatelem świata.

2. Respektowanie kultury i zwyczajów każdego kraju oraz współuczestnictwo i wkład w jego rozwój gospodarczy i społeczny poprzez naszą działalność na rzecz społeczności lokalnych.

3. Nieustanne podejmowanie działań na rzecz zapewnienia czystych i bezpiecznych produktów oraz poprawy jakości życia poprzez całość prowadzonych przez nas działań.

4. Tworzenie i rozwijanie zaawansowanych technologii oraz zapewnianie produktów i usług najwyższej jakości, odpowiadających na potrzeby klientów na całym świecie. 
Szczególne znaczenie ma deklarowanie kluczowych wartości, jakimi korporacja zobowiązuje się kierować w stosunkach zatrudnienia. W nomenklaturze Międzynarodowej Organizacji Pracy określa się je jako podstawowe prawa człowieka (ang. basic human rights) związane z pracą (zakazy dyskryminacji, zakazy tolerowania pracy niewolniczej, pracy dzieci itp.).

Korporacja zobowiązuje się do poszanowania tych zasad-wartości nie tylko przez siebie samą i jej filie, ale również do spowodowania ich przestrzegania przez dostawców i podwykonawców, których korporacja dobiera do realizacji swoich zadań. W tym zakresie treść kodeksów pozostaje w korelacji z konwencjami MOP oraz innymi fundamentalnymi aktami i deklaracjami prawa międzynarodowego i europejskiego, promującymi podstawowe prawa człowieka w dziedzinie społecznej.

Kolejny blok tematyczny odnosi się do praktyk z zakresu pracy. Obejmuje m.in. takie zagadnienia, jak bezpieczeństwo i higiena pracy, szkolenia, stabilizacja zatrudnienia, czas pracy, wynagrodzenia, co najczęściej sprowadza się do stwierdzenia, że wynagrodzenie powinno być uczciwe $^{12}$. Obejmuje także współpracę ze związkami zawodowymi, problematykę dialogu społecznego, warunki zawierania układów zbiorowych i inne kwestie z zakresu zbiorowych stosunków pracy. W tym obszarze kodeksy etyczne pozostają w treściowym powiązaniu ze źródłami prawa 144 pracy na płaszczyźnie międzynarodowej i krajowej.

Niewątpliwie największy ciężar gatunkowy w treści kodeksów mają postanowienia zaliczane do dziedziny tzw. praktyk operacyjnych ${ }^{13}$, dotyczące w szczególności zasad postępowania w stosunku do klientów, czyli podmiotów sprzedających swoje produkty lub usługi korporacji bądź na-

5. Tworzenie korporacyjnej kultury zachęcającej do indywidualnej kreatywności i propagującej wartości pracy zespołowej, przy jednoczesnym kreowaniu wzajemnego zaufania i poszanowania pomiędzy pracownikami i kierownictwem.

6. Dążenie do rozwoju w harmonii ze społecznością globalną poprzez innowacyjne metody zarządzania.

7. Współpraca z partnerami biznesowymi w badaniach i tworzeniu w celu osiągnięcia stabilnego, długoterminowego rozwoju i uzyskania wzajemnych korzyści, przy równoczesnym otwarciu na nowe relacje partnerskie.

${ }^{12}$ Jak pisze B. Surdykowska, cytując dane zawarte w ekspertyzach Międzynarodowego Biura Pracy, do występujących najczęściej postanowień kodeksów dotyczących standardów pracy należą zakazy dyskryminacji, normy odnoszące się do bezpieczeństwa i higieny pracy oraz ogólne zasady kształtowania i wypłaty wynagrodzeń. Por. tej autorki Kodeksy dobrych praktyk, „Kontrola Państwowa” 2008, nr 4, s. 134-136.

${ }_{13}$ Takim terminem posłużono się w dokumencie Wytyczne dotyczace społecznej odpowiedzialności, PN-ISO (Międzynarodowa Organizacja Normalizacyjna) 26000, Warszawa 2012. Zgodnie z ISO 26000, w skład uczciwych praktyk operacyjnych wchodzą następujące zagadnienia: przeciwdziałanie korupcji, odpowiedzialne angażowanie się $\mathrm{w}$ działalność polityczną, uczciwa konkurencja, promowanie społecznej odpowiedzialności w łańcuchu wartości, poszanowanie praw własności. 
bywających je od korporacji w celach komercyjnych ${ }^{14}$. Na czoło w tym zakresie wysuwają się postanowienia antykorupcyjne, w szerokim tego słowa znaczeniu. Zasadniczą ich funkcja, poza ochroną własnych zasobów, jest zapewnienie uczciwej konkurencji między podmiotami uczestniczącymi w grze rynkowej, co stanowi wymóg ładu gospodarczego w warunkach wolnej konkurencji. Postanowienia z tego zakresu cechuje większa szczegółowość, a nawet drobiazgowość, co odróżnia je od ogólnikowości cechującej z reguły inne postanowienia kodeksów.

Przedmiotem drobiazgowej niekiedy reglamentacji pozostaje m.in. sposób postępowania $\mathrm{w}$ sytuacji wręczania pracownikom upominków przez przedstawicieli klientów firmy i vice versa, gdy prezenty wręczane są osobom, z którymi firma utrzymuje kontakty handlowe. I tak przykładowo, według kodeksu etycznego obowiązującego w koncernie Philipsa, „niedopuszczalne jest przyjmowanie upominków lub korzyści osobistych o wartości handlowej z wyjątkiem prezentów o wartości nie przekraczającej 50 euro, jeżeli prezent został wręczony dobrowolnie i jeżeli nie zachodzi uzasadnione prawdopodobieństwo, iż wpłynie to na osąd lub działanie w trakcie wypełniania obowiązków z ramienia Philipsa. Gdyby nie wypadało odmówić przyjęcia prezentu, należy go bezzwłocznie przekazać odpowiedniej osobie odpowiedzialnej za przestrzeganie zasad".

Philips przekazuje takie dary instytucjom charytatywnym (ust. 33). Z kolei upominki dla osób z zewnątrz mogą być przekazywane wyłącznie $\mathrm{w}$ formie grzeczności biznesowej, pod warunkiem, że praktyka taka jest akceptowana w danym kraju i sektorze gospodarki. Upominki przekraczające określoną wartość (100 lub 200 euro) powinny być wpisywane do rejestru upominków Philipsa. Ważnymi przejawami nietolerowanych w świetle kodeksów zachowań jest m.in. podejmowanie działalności konkurencyjnej wobec własnego pracodawcy oraz praktykowanie nepotyzmu.

Instytucją mającą podstawy w kodeksach etycznych, służącą w szczególności przeciwdziałaniu korupcji, jest ustalanie wewnętrznych procedur umożliwiających każdemu pracownikowi zgłaszanie informacji i podejrzeń dotyczących zaobserwowanych nieprawidłowości osobom odpowiedzialnym za ich przyjmowanie i nadawanie dalszego biegu (tzw. whistleblowing $)^{15}$.

${ }^{14}$ Według ISO 26000 klientem jest organizacja lub osoba fizyczna dokonująca zakupu nieruchomości, produktów lub usług bądź korzystająca z nieruchomości, produktów lub usług w celach komercyjnych, prywatnych albo publicznych.

15 Termin ten znaczy dosłownie "dmuchanie w gwizdek". Whistleblowers określani są w polskim piśmiennictwie jako sygnaliści (por. M. Derlacz-Wawrowska, "Whistleblowing” a ochrona informacji poufnych pracodawcy, [w:] Prawo pracy. Refleksje i poszukiwania. Ksiegga jubileuszowa Profesora Jerzego Wratnego, red. G. Uścińska, Warszawa 2013, s. 390) lub „bijący na alarm” (por. M. Rybak, Etyka menedżera - społeczna odpowiedzialność przedsiębiorstwa, Warszawa 2004, s. 155-156). 
I tak np. zgodnie z Kodeksem Etyki Biznesu obowiązującym w Grupie Deutsche Telekom AG, właścicielu sieci T-Mobile, zachęca się wszystkich pracowników do sygnalizowania nieprawidłowości z ewentualnym anonimowym wykorzystaniem otwartego specjalnie $w$ tym celu portalu Tip - off (Tell me!). W holdingu Porsche (powiązanym z Volkswagenem) informacje o "śladach korupcji” można zgłaszać do jednego z dwóch rzeczników Praw Obywatelskich Grupy, którymi są powołani przez Grupę prawnicy, działający na zewnątrz korporacji, uprawnieni do przyjmowania tego rodzaju informacji i przekazywania ich do kierownictwa koncernu. Kodeksy zapewniają ochronę działającym w dobrej wierze sygnalistom, jak również osobom bezpodstawnie pomówionym.

Do postanowień dotyczących praktyk operacyjnych zalicza się także poszanowanie praw własności intelektualnej czy postulaty oględności $\mathrm{w}$ manifestowaniu $\mathrm{w}$ stosunkach służbowych poglądów politycznych i religijnych. Korporacje z reguły podkreślają też swoją apolityczność.

Postanowienia zaliczane do dziedziny praktyk operacyjnych mają swoje odpowiedniki w licznych regulacjach prawnych, wśród których dominującą rolę odgrywają przepisy o przeciwdziałaniu nieuczciwej konkurencji, jakiej dopuszczać się mogą zarówno podmioty gospodarcze w relacjach biznesowych, jak i osoby fizyczne względem swojej korporacji1'.

Dalszą grupę interesariuszy, do których odnoszą się niekiedy kodeksy dobrych praktyk, stanowią konsumenci, czyli osoby fizyczne nabywający produkty i usługi spółki w celach prywatnych ${ }^{17}$. Chodzi zatem o ogniwo finalne działalności gospodarczej.

Przykładami postanowień nawiązujących do społecznej odpowiedzialności korporacji względem konsumentów jest dostarczanie prawdziwej, obiektywnej informacji, uczciwa reklama, sprawne i rzetelne rozstrzyganie reklamacji, ochrona zdrowia nabywców, jak również nieoferowanie produktów powstających wskutek zatrudnienia dzieci, wyzysku siły roboczej itp., które to praktyki mogą występować w firmach korporacji lub u podwykonawców w krajach tzw. Trzeciego Świata. Postanowienia należące do tej grupy są powiązane $\mathrm{z}$ międzynarodowymi i krajowymi przepisami mającymi przeciwdziałać nieuczciwym praktykom $\mathrm{w}$ handlu ${ }^{18}$.

„Milczącym interesariuszem”, któremu w pewnej liczbie kodeksów etycznych poświęca się sporą uwagę, jest środowisko naturalne. Korporacje deklarują chęć uczestniczenia w wysiłkach na rzecz ochrony środowi-

${ }^{16}$ W Polsce jest to w szczególności ustawa z dnia 16 kwietnia 1993 r. o zwalczaniu nieuczciwej konkurencji, DzU, 2003, nr 153, 1503, tj. z późn. zm.

${ }_{17}$ Cel prywatny jako wyróżnik zachowania się konsumenta względem dóbr świadczonych przez korporację podkreślono w ISO 26000.

${ }_{18}$ W Polsce por. w szczególności ustawę z dnia 16 lutego 2007 r. o ochronie konkurencji i konsumentów (DzU, 2007, nr 50, poz. 331 z późn. zm.) oraz cytowaną wcześniej ustawę o nieuczciwych praktykach handlowych. 
ska przed zanieczyszczeniami, niekorzystnymi zmianami klimatycznymi, w ochronie gatunkowej roślin i zwierząt. Ideą przewodnią uwzględniania aspektów ekologicznych jest pojęcie zrównoważonej konsumpcji i zrównoważonego rozwoju, służące zachowaniu ograniczonych zasobów przyrody dla przyszłych pokoleń. W tym zakresie korporacje zobowiązują się do wspierania wysiłków państw i organizacji międzynarodowych (pakiety klimatyczne itp.).

Korporacje deklarują następnie chęć podejmowania długoterminowych działań we współpracy ze społecznością lokalną i na jej rzecz, takich jak np. przeciwdziałanie bezrobociu i społecznej marginalizacji bezrobotnych, świadczenie pomocy przy organizowaniu programów kształcenia zawodowego i obywatelskiego.

Na szczycie tzw. piramidy społecznej odpowiedzialności Carrolla ${ }^{19}$ znajduje się aktywność filantropijna korporacji, czyli dobrowolne finansowanie nakładów infrastrukturalnych w zdrowie, oświatę, kulturę i inne dziedziny mające na celu, jak to się określa, podźwignięcie cywilizacyjne danej okolicy, regionu czy kraju, w tym także dotowanie organizacji dobroczynnych.

Kodeksy dobrych praktyk $z$ definicji mają charakter etyczny, a nie prawny. Chociaż z założenia nie stanowią źródeł prawa, to jednak można wskazać wiele przesłanek świadczących o tym, że nie są one prawnie całkowicie irrelewantne.

1. Po pierwsze, pod względem językowym i strukturalnym upodabniają się do wypowiedzi prawnych, ponieważ zbudowane są ze zdań powinnościowych cechujących etykę normatywną. Jako że dotyczą materii prawnej, chociaż bez odwoływania się do sankcji prawnych (od czego zresztą zachodzą wyjątki), można stwierdzić, że postanowienia kodeksów, uwzględniając wszelkie zastrzeżenia, funkcjonują jako sui generis substytut norm prawnych.

2. Jak o tym była już mowa, kodeksy dobrych praktyk zawierające zbiory wartości, tyleż uniwersalnych, co korporacyjnych, mają w swej warstwie werbalnej charakter przede wszystkim aksjologiczny i wizerunkowy. Trudno w tym zakresie doszukiwać się jakichś wyraźnych implikacji prawnych, chociaż przy dochodzeniu odpowiedzialności na płaszczyźnie etycznej bądź prawnej można zawsze podnosić zarzut, że korporacja postępuje wbrew wyznawanym wartościom.

3. Deklarowane wartości, należące zwłaszcza do puli praw człowieka (jak np. zakaz pracy dzieci), mogą przyczyniać się do promowania standardów cywilizacyjnych wywodzących się z kręgu kultury zachodniej w krajach Trzeciego Swiata, na które rozciąga się działalność korporacji.

${ }^{19}$ Chodzi tu o opracowany przez amerykańskiego uczonego A.B. Carrolla czteropoziomowy model piramidy społecznej odpowiedzialności przedsiębiorstwa. Por. M. Rybak, Etyka menedżera..., s. 228-229. 
4. W kodeksach dobrych praktyk, zwłaszcza wydawanych przez organizacje gospodarcze rozgałęzione na wiele krajów, eksponuje się zasadę, według której postanowienia kodeksowe pozostają w zgodności z prawem miejscowym. Ta zasada legalizmu ma wielorakie implikacje. Po pierwsze, a priori wyklucza się sprzeczność między prawem krajowym a postanowieniem kodeksów. Po drugie, pozostawia się kodeksom wolną przestrzeń, w tym zakresie, w jakim sprzeczność taka nie występuje. Po trzecie, podkreślenie zgodności z prawem miejscowym umacnia autorytet tego prawa w stosunkach korporacji z interesariuszami. Po czwarte, co dotyczy stosunków pracy, zasada zgodności z prawem miejscowym nie wyklucza odstępstw na korzyść pracowników, jak np. postanowienia spotykane także w kodeksach korporacji działających w Polsce, stanowiące, że podejmowanie pracy $\mathrm{w}$ godzinach nadliczbowych jest dla pracownika dobrowolne. Można to - odwołując się do klauzuli korzystności - potraktować jako wytyczną dla stanowienia prawa zakładowego bądź uznać, że sam kodeks jest w tym zakresie aktem prawa zakładowego ${ }^{20}$.

5. W ramach swobody regulacyjnej, uwzględniającej zasadę legalizmu, występuje szereg rozwiązań będących oryginalnym dorobkiem kodeksów dobrych praktyk. Jak wspomniano, skupiają się one w szczególności w obrębie praktyk operacyjnych i dotyczą postanowień mających przeciwdziałać korupcji. Nakładają na pracowników określone obowiązki, mające przede wszystkim postać powstrzymywania się od pewnych zachowań. Kształtują zatem pod tym względem status pracowniczy. Obligatoryjność przestrzegania $\mathrm{w}$ tej dziedzinie dobrych praktyk wzmacniana jest niekiedy zagrożeniem zastosowania sankcji o charakterze dyscyplinarnym bądź odszkodowawczym, co - w braku rozwiniętej regulacji w samym kodeksie - należy traktować jako odesłanie do odpowiednich przepisów prawnych. Tym samym można mówić o pośredniej jurydyzacji postanowień $z$ założenia mających charakter etyczny. W nawiązaniu do obowiązującego w Polsce zakładowego systemu źródeł prawa pracy, postanowienia, o których mowa, należałoby w zasadzie zaliczyć do materii regulaminu pracy, chociaż ich obszerność i szczególny charakter predestynuje je do oddzielnej regulacji. Z punktu widzenia kwalifikacji stosunku pracy jako zobowiązania, $\mathrm{w}$ ramach którego pracownik świadczy pracę $\mathrm{w}$ warunkach podporządkowania, omawiane postanowienia kodeksów mieszczą się w sferze uprawnień kierowniczych pracodawcy. $\mathrm{Na}$ gruncie kodeksu pracy można by przyjąć, że uprawnienia te realizo-

${ }^{20}$ Promocyjna funkcja kodeksów bywa jednak podawana w wątpliwość. I tak, zdaniem J. Oniszczuka „,trudno sformułować tezę, że działalność korporacji służy z założenia podwyższaniu standardu praw socjalnych w poszczególnych państwach i na świecie". Por. J. Oniszczuk, Prawo pracy a korporacje transnarodowe, [w:] Korporacje transnarodowe. Jeden temat, różne spojrzenia, red. J. Menkes, T. Gardocka, Warszawa 2010, s. 323. 
wane są $\mathrm{w}$ ramach pracowniczego obowiązku dbałości o zakład pracy (lojalność, przestrzeganie tajemnic, dbanie o wizerunek firmy, społeczny obowiązek sygnalizowania o nieprawidłowościach połączony z ochroną sygnalistów itp.).

6. Kontynuując rozważania na temat znaczenia prawnego kodeksów etycznych zwróćmy z kolei uwagę na ich rolę integrująca, co dotyczy organizacji o złożonej strukturze. Kodeks dobrych praktyk w korporacji o strukturze holdingowej, gdzie mamy do czynienia ze spółką dominującą oraz spółkami zależnymi, ustalony na szczeblu centralnym piramidy spółek i jednolity dla całej organizacji, stanowi zamanifestowanie jedności takiej struktury, co nie jest bez znaczenia dla obrotu prawnego. Również dla prawa pracy z faktu tego wyprowadzić można interesujące implikacje. Jak pisze P. Czarnecki „,dokumenty tego rodzaju [...] ułatwiają śledzenie zachodzących powiązań, stanowią istotny dowód wpływu spółki dominującej na spółki zależne objęte działaniem tego samego kodeksu postępowania, także jeżeli chodzi o kwestie związane z zatrudnianiem pracowników"21.

Wyśledzenie $\mathrm{w}$ takiej strukturze istnienia pracodawcy właścicielskiego (rzeczywistego, konstytucyjnego), mającego choćby ograniczoną (odcinkową) podmiotowość pracodawcząa2, wspiera pogląd o możliwości zastosowania w prawie pracy koncepcji „unoszenia zasłony osobowości prawnej"23, co może poprawić sytuację pracownika w zakresie dochodzenia od pracodawcy roszczeń i odpowiedzialności np. wtedy, gdy spółka zależna zatrudniająca pracownika okaże się niewypłacalna.

7. Należy zwrócić uwagę na postępujący proces uwzględniania kodeksów etycznych w obowiązującym stanie prawnym w Polsce. Przejawem tego rodzaju pozytywizacji jest cytowana już wcześniej ustawa z 23 sierpnia 2007 r. o przeciwdziałaniu nieuczciwym praktykom rynkowym (będąca efektem wdrożenia odpowiedniej dyrektywy UE), definiująca pojęcie kodeksu dobrych praktyk i określająca rolę kodeksów w przeciwdziałaniu nieuczciwym praktykom rynkowym ${ }^{24}$. Warto też odnotować, że w wyniku

${ }^{21}$ P. Czarnecki, Odpowiedzialność pracodawcy ..., s. 157.

22 Tezę o przysługiwaniu spółce dominującej „odcinkowej zdolności pracodawczej” względem spółek zależnych uzasadniał Z. Kubot. Por. tego autora Odcinkowa zdolność pracodawcza spółki dominującej w grupie kapitałowej, „Praca i Zabezpieczenie Społeczne” 2014, nr 9 oraz tegoż autora Rola spółki dominującej w sporze zbiorowym pracowników spótki zależnej, „Praca i Zabezpieczenie Społeczne” 2014, nr 10.

${ }^{23}$ P. Czarnecki, Odpowiedzialność pracodawcy..., s. 157.

${ }^{24}$ Charakter prawny kodeksów dobrych praktyk i ich rolę w obrocie prawnym na gruncie ustawy z 23 sierpnia 2007 r. szeroko omówiono w wyroku Sądu Okręgowego - Sądu Ochrony Konkurencji i Konsumentów z dnia 11 lutego 2013 r. (XVII AmA 44/11). Według Sądu mamy do czynienia z instrumentem samoregulacyjnym zawierającym „zbiór zasad, które określają sposób zachowania przedsiębiorców i do których przestrzegania zobowiązali się sami przedsiębiorcy". W sektorach, w których istnieją szczególne obliga- 
nowelizacji kodeksu cywilnego w 2003 r. dodano przepis, zgodnie z którym przedsiębiorca składający ofertę w postaci elektronicznej jest obowiązany przed zawarciem umowy poinformować drugą stronę w sposób jednoznaczny i zrozumiały m.in. o kodeksach etycznych, które stosuje, oraz o ich dostępności w postaci elektronicznej (por. art. $66^{1} \S 2$ pkt 6).

\section{***}

W literaturze podkreśla się, że na funkcjonowanie życia gospodarczego w Polsce w coraz większym stopniu wpływa „misyjność ponadnarodowych korporacji gospodarczych. Według głoszonej przez korporacje ideologii misją ich jest traktowanie organizacji gospodarczej jako wspólnoty, która ucieleśniona w kodeksach dobrego postępowania stanowi wewnątrz korporacji odpowiednik konstytucji w państwie ${ }^{25}$. Poza inicjatywami wychodzącymi od samych korporacji obserwuje się jednocześnie rosnący nacisk ze strony Unii Europejskiej na wdrożenie w firmach zasad społecznej odpowiedzialności biznesu, czego instrumentem są w szczególności kodeksy dobrych praktyk ${ }^{26}$.

Przeprowadzone w niniejszym tekście analizy świadczą o możliwości i celowości rozszerzenia zainteresowania nauki prawa, w tym nauki prawa pracy, nowymi zjawiskami, jakie przynosi pogłębiający się proces globalizacji, które mogą w istotnym stopniu determinować rozwój m.in. tej gałęzi „prawa” w nieodległej przyszłości.

\section{Bibliografia}

Adamczyk S., Surdykowska B., Międzynarodowe układy ramowe jako przykład dobrowolnie podejmowanych negocjacji między praca a kapitałem, [w:] Układy zbiorowe pracy. W stulecie urodzin Profesora Wacława Szuberta, red. naukowa Z. Góral, Lex Wolters Kluwer business, Warszawa 2013.

toryjne wymogi regulujące postępowanie przedsiębiorców, postanowienia kodeksów powinny m.in. "stanowić podstawę oceny staranności zawodowej w określonym sektorze" (z uzasadnienia do wyroku z powołaniem się na dyrektywę 2005/29 WE).

${ }^{25}$ Por. J. Oniszczuk, Prawo pracy..., s. 334-335.

${ }^{26}$ Jak podało ostatnio Ministerstwo Finansów, zgodnie z dyrektywą Unii Europejskiej z połowy listopada 2014, zmieniającą dyrektywę o rachunkowości, Polska najpóźniej od 1 stycznia 2017 r. będzie zmuszona do egzekwowania od większych spółek obowiązku składania sprawozdań ze stosowania polityki CSR, a nadto pewna liczba spółek giełdowych będzie miała obowiązek prowadzenia tzw. polityki różnorodności, czyli stosowania parytetów w zakresie różnych kryteriów obsady stanowisk w organach spółki (http:// www.lex.pl/czytaj/-/artykul/wieksze-firmy-beda-oglaszac-raporty-nt-polityki-csr; dostęp: 2.12.2014). 
Adamczyk S., Surdykowska B., Ponadnarodowe układy ramowe jako próba odpowiedzi związków zawodowych na wyzwania globalizacji, „Praca i Zabezpieczenie Społeczne” 2012, nr 1.

Boruta J., W sprawie przyszłości prawa pracy, „Praca i Zabezpieczenie Społeczne” 2005, nr 4.

Craig J., Lynk M., Labour Law and Globalization, [w:] Globalization and the Future of Labour Law, J.D.R. Craig, S.M. Lunk (eds), Cambridge University Press, Cambridge 2006.

Czarnecki P., Odpowiedzialność pracodawcy a rozwój struktur holdingowych, Warszawa 2014, s. 35.

Derlacz-Wawrowska M., "Whistleblowing” a ochrona informacji poufnych pracodawcy, [w:] Prawo pracy. Refleksje i poszukiwania. Księga jubileuszowa Profesora Jerzego Wratnego, red. G. Uścińska, Warszawa 2013.

Dryll I., Grakowska A., Jak walczyć z korupcja i przestępczościa w biznesie? Kodeksy etyczne i polityka sygnalistów na świecie”. Sprawozdanie z konferencji, „Dialog” 2014, nr 3, s. 94-96.

Gładoch M., Dialog społeczny w zbiorowym prawie pracy, Torun 2014.

Jagodziński R., Europejskie negocjacje zbiorowe. Nowe formy dialogu na poziomie UE, „Dialog” 2011, nr 1, s. 27-44.

Kubot Z., Odcinkowa zdolność pracodawcza spółki dominującej w grupie kapitałowej, „Praca i Zabezpieczenie Społeczne" 2014, nr 9.

Kubot Z., Rola spótki dominującej w sporze zbiorowym pracowników spótki zależnej, „Praca i Zabezpieczenie Społeczne" 2014, nr 10.

Mamica I., Business and Code of Conduct Implementation, Geneve 2006.

Oniszczuk J., Prawo pracy a korporacje transnarodowe, [w:] Korporacje transnarodowe. Jeden temat, różne spojrzenia, red. J. Menkes, T. Gardocka, Warszawa 2010.

Rybak M., Etyka menedżera - społeczna odpowiedzialność przedsiębiorstwa, Warszawa 2004.

Rymkiewicz B., Społeczna odpowiedzialność biznesu a prawo pracy, [w:] Studia z zakresu prawa pracy i polityki społecznej, red. A. Świątkowski, Kraków 2014.

Surdykowska B., Kodeksy dobrych praktyk, „Kontrola Państwowa” 2008, nr 4, s. 134-136.

\section{Codes of Good Practices as the Expression of Social Responsibility of Corporations}

\section{Summary}

The author draws attention to the process of internationalization of Polish labour law. One of its stages was to assimilate the achievements of the International Labour Organization, Council of Europe and the European Union social law. The challenge now is the law created by transnational corporations through agreements with the employees or by self-regulation by the same companies. The results of this self-regulation are primarily codes of conduct, which are expression of the so-called corporate social responsibility. Codes of ethics are becoming labor law issue. The author analyzes the relationship between the provisions of the codes and the national legal order, particularly in the area of labour relations, pointing at the progressive transformation of ethical rules into legal ones. 